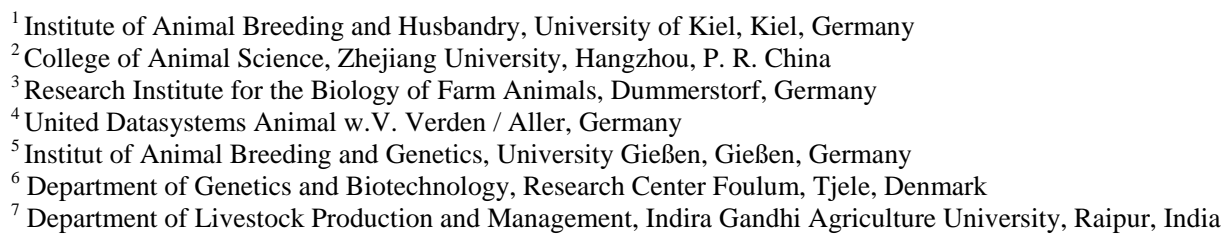

NINGYING XU ${ }^{1,2}$, SVEN PAUL ${ }^{1}$, JÖRN BENNEWITZ ${ }^{1}$, NORBERT REINSCH ${ }^{3}$, GEORG THALLER $^{1}$, FRIEDRICH REINHARDT ${ }^{4}$, CHRISTA KÜHN $^{3}$, MANFRED SCHWERIN $^{3}$, GEORG ERHARDT ${ }^{5}$, CHRISTINA WEIMANN ${ }^{5}$, HAUKE THOMSEN ${ }^{6}$, SHARAD MISHRA $^{1,7}$ and ERNST KALM ${ }^{1}$

\title{
Confirmation of quantitative trait loci for somatic cell score on bovine chromosome 18 in the German Holstein
}

\begin{abstract}
Fifty-one half-sib families with 2768 sires were selected for this study to confirm a quantitative trait locus (QTL) detected within a previous project initiated by the German Cattle Breeders Federation (ADR). The data based on a granddaughter design were divided into two parts and were analysed using linear models and paternal half sib regression methods. The results strongly support the hypothesis that the chromosomal region around marker TGLA227 at the telomeric end of chromosome 18 harbours a QTL for somatic cell score (SCS) in the German Holstein population. Using a two-QTL model the analysis showed evidence for another QTL for SCS in that region on chromosome 18. Further fine mapping studies should be carried out to decide on the two QTL hypothesis.
\end{abstract}

Key Words: somatic cell score, German Holsteins, udder health, QTL, chromosome 18

\section{Zusammenfassung}

Titel der Arbeit: Untersuchung zu Quantitativ Trait Loci für somatische Zellzahl auf dem bovinen Chromosom 18 bei Deutschen Holsteins unter Verwendung zweier Granddaughter-Designs

Einundfünfzig Halbgeschwisterfamilien mit 2768 Söhnen wurden für eine Bestätigungsstudie selektiert. Die Daten auf Grundlage eines Granddaughter-Designs wurden in zwei Gruppen geteilt und mit linearen Modellen und paternalen Halbgeschwister-Regressionen analysiert. Das Ergebnis zeigt, dass der Marker TGLA227 in einigen Familien der Deutschen-Holstein-Population am Ende des Chromosoms 18 gekoppelt ist mit einem QTL für somatische Zellzahl (SCS). Unter Verwendung eines Zwei-QTL-Modells konnte ein Hinweis für einen weiteren QTL in diesem Bereich auf Chromosom 18 erbracht werden.

Schlüsselwörter: Somatische Zellzahl, Deutsche Holsteins, Eutergesundheit, QTL, Chromosom 18

\section{Introduction}

Somatic cell score (SCS) is a well known indicator trait for mastitis resistance and is implemented in the routine sire evaluation in many countries. Meanwhile, many quantitative trait loci (QTL) affecting SCS have been reported (http://www.vetsci.usyd.edu.au/reprogen/QTL_Map). In particular, the marker TGLA227 as well as other telomeric regions of BTA18 have repeatedly shown to harbour QTL for SCS (ASHWELL et al., 1997; SCHROOTEN et al., 2000; RODRIGUEZ-ZAS et al., 2002; BRINK, 2003; KÜHN et al., 2003; HOLMBERG and ANDERSSON-EKLUND, 2004; SCHULMAN et al., 2004). In the same region a genomewide significant QTL for clinical mastitis was detected (SCHULMAN et al., 
2004). Additionally, on this chromosome QTL were identified for functional traits such as herd life, maternal and direct effect of dystocia, maternal and direct effect of stillbirth, and maternal and paternal effect of nonreturn rate of 90 days (KÜHN et al., 2003).

Before implementing a QTL in actual breeding schemes through marker assisted selection (MAS) in a certain population, it first has to be confirmed in the population due to uncertainty about the validity of the identified QTL and its segregation in the breeding population (SPELMAN and BOVENHUIS, 1998).

The aim of this study was to confirm the QTL for SCS on BTA18 in the German Holstein population reported by KÜHN et al. (2003) and to discover heterozygous families segregating for this QTL.

\section{Materials and Methods \\ Animals and genotypes}

Two different and distinct granddaughter designs (i.e. no overlap between the designs) were analysed consisting of altogether 2768 progeny tested German Holstein dairy cattle bulls. The bulls of the first granddaughter design were genotyped at the marker TGLA227 during routine parentage testing. Non-informative families, non-informative sires and sires involved in a conflict (i.e., TGLA227 homozygous grandsires, paternally inherited TGLA227 allele not identifiable, and violation of the Mendelian laws of inheritance, respectively) were excluded. The final size of this granddaughter design was 752 animals from 14 families; the average family size was 54 and varied from 30 to 114. This granddaughter design will be termed first data set in the following.

The animals of the second granddaughter design were genotyped at five microsatellite markers located on BTA18 (i.e., TGLA227, BM2078, BMS2639, ILSTS002 and BM7109). Conflicting sires were excluded from the data set. Finally, it consisted of 36 families with 2016 animals. The average family size was 56, ranging from 26 to 123. CRI-MAP was used to compute a genetic linkage map (GREEN et al., 1990). This granddaughter design will be termed second data set in the following.

\section{Table 1}

Number of records (N), means, standard deviation (Std.dev.), minimum and maximum for daughter yield deviations of somatic cell score and de-regressed breeding values of somatic cell score (Zahl der Beobachtungen (N), Mittelwerte (Mean), Standardabweichungen (Std.dev), Minimum und Maximum für durchschnittliche korrigierte Töchterabweichung für somatische Zellzahl und deregressierte Zuchtwerte für somatische Zellzahl)

\begin{tabular}{lrrrrr}
\hline Trait class & $\mathrm{N}$ & \multicolumn{1}{c}{ Mean } & Std.dev. & \multicolumn{1}{c}{ Min. } & Max. \\
\hline DYD & & 0.0012 & 0.337 & -0.832 & 1.425 \\
DYCS-1L & 1946 & 0.0151 & 0.402 & -2.069 & 1.601 \\
DYCS-2L & 1515 & 0.0083 & 0.402 & -1.065 & 1.609 \\
DG-RZS & 550 & 119.6354 & 15.545 & 65.909 & 182.456 \\
\hline
\end{tabular}

DYD $_{\mathrm{SCS}-1 \mathrm{~L}}, \mathrm{DYD}_{\mathrm{SCS}-2 \mathrm{~L}}$, DYD $\mathrm{SCS}-3 \mathrm{~L}_{\mathrm{L}}$ : daughter yield deviations for 1., 2., 3. lactation; DG-RZS: de-regressed estimated breeding value of somatic cell score

\section{Phenotypes}

Phenotypes for both data sets were provided by the Vereinigte Informationssysteme Tierhaltung w.V. (VIT). Four classes of phenotypic data were available for the trait somatic cell score (SCS): daughter yield deviations for the first $\left(\mathrm{DYD}_{\mathrm{SCS}-1 \mathrm{~L}}\right)$, for the second (DYD $\left.\mathrm{D}_{\mathrm{SCS}-2 \mathrm{~L}}\right)$ and for the third lactation $\left(\mathrm{DYD}_{\mathrm{SCS}-3 \mathrm{~L}}\right)$ and, additionally, estimated breeding values (DG-RZS). The latter were de-regressed as described by THOMSEN 
et al. (2001). Note that not all sires had an observation for each of the four SCS phenotypic classes, see Table 1. For the analysis of effects on other traits putatively linked to the SCS QTL, de-regressed estimated breeding values were used for five milk traits and eight functional traits (see KÜHN et al., 2003).

\section{Statistical analysis}

Both data sets were analysed by weighted linear models. The weighting factors were calculated for each phenotypic observation as described by SPELMAN et al. (1996) in order to account for the different number of daughters' contribution to the phenotype of the sire. The corresponding heritabilities were taken as for the routine sire evaluations (see http://www.vit.de).

The first data set was analysed by the following single marker model using the SAS GLM procedure (SAS Institute, Cary, NC):

$y_{i j}=g s_{i}+m_{i k}+e_{i j}$,

where $y_{i j}$ is the trait value of the jth son of the ith grandsire, $g s_{i}$ is the fixed effect of the ith grandsire, $m_{i k}$ is the fixed effect of the kth paternally inherited TGLA227 marker allele nested within grandsire $\mathrm{i}$, and $e_{i j}$ is the random residual.

The second data set was analysed by a multi-marker regression (KNOTT et al., 1996) using the following model:

$$
y_{i j k}=g s_{i}+b_{i k} \times P_{i j k}+e_{i j k} \text {, }
$$

where $y_{i j k}$ is the trait value of the jth son of the ith grandsire, $g s_{i}$ is the fixed effect of the ith grandsire, $b_{i k}$ is the regression coefficient for the ith grandsire at the kth chromosomal location, $P_{i j k}$ is the probability of the jth son receiving the chromosomal segment of the first gamete from the ith grandsire at kth chromosomal position, and $e_{i j k}$ is the random residual. The software package QTL Express (http://qtl.cap.ed.ac.uk), as described by SEATON et al. (2002), was used for the multi-marker regression. A chromosomewise significance threshold was determined by applying the permutation test with 10,000 permutations for the trait SCS and 1000 permutations for all other traits. Regression analysis was applied every cM along the chromosome.

Grandsires putatively heterozygous at the QTL for the trait SCS were identified by contrasting the two paternal half-sib groups with respect to their inheritance of the paternal TGLA227 marker allele (first data set) and with respect to their inheritance of the paternal haplotype at the estimated QTL position (second data set). The null hypothesis was that the grandsire was homozygous at the QTL, this was tested by a ttest, resulting in a pointwise error probability $\left(\mathrm{p}_{\text {pointwise }}\right)$ for each test conducted. This resulted in a multiple testing problematic, and for a chosen pointwise significance level it is expected that some tests are significant merely by chance. Therefore, the $\mathrm{p}_{\text {pointwise }}$ were converted into experimentwise error probabilities ( $\mathrm{p}_{\text {experimentwise }}$ ) using the Bonferroni correction: Pexperimentwise $=1-\left(1-\mathrm{p}_{\text {pointwise }}\right)^{\mathrm{m}}$, where $\mathrm{m}$ is the number of families for the respective SCS phenotypic class, with $\mathrm{m}=43$ for $\mathrm{DYD}_{\mathrm{SCS}-1 \mathrm{~L}}, \mathrm{~m}=35$ for $\mathrm{DYD}_{\mathrm{SCS}-2 \mathrm{~L}}, \mathrm{~m}=14$ for $\mathrm{DYD}_{\mathrm{SCS}-3 \mathrm{~L}}$ and $\mathrm{m}=51$ for $\mathrm{DG}-\mathrm{RZS}$, respectively. Additionally, the concept of the false discovery rate was applied to account for this multiple testing problem: the 51 tests (i.e. 51 families were tested for QTL 
segregation) were ordered according to their $\mathrm{p}_{\text {pointwise }}$ and then for each test a $q$ value was estimated as described by BENJAMINI and HOCHBERG (1995). The $q$ value of a particular test $i$ can be interpreted as the false discovery rate if all tests with lower or equal $p_{\text {pointwise }}$ compared to the test $i$ are defined as significant. The heterozygous families are shown in Table 3.

Additionally, for the trait somatic cell score a two-QTL model implemented in a grid search using QTL Express was fitted to the second data set as follows:

$y_{i j k 1 k 2}=g s_{i}+b_{i k 1} \times P_{i j k 1}+b_{i k 2} \times P_{i j k 2}+e_{i j k 1 k 2}$,

where $k 1$ and $k 2$ refer to the position of the first and second QTL. Other terms are as defined in the one-QTL model. The minimum distance between the first and second investigated chromosomal position was set to $4 \mathrm{cM}$.

\section{Results}

The analysis of the first data set revealed a significant effect of the marker TGLA227 for the phenotypic classes $\mathrm{DYD}_{\text {SCS-1L }}\left(\mathrm{p}_{\text {pointwise }}=0.0196\right)$, DYD $\mathrm{DCS}-2 \mathrm{~L}\left(\mathrm{p}_{\text {pointwise }}\right.$ $=0.0438), D_{\text {SCS-3L }}\left(p_{\text {pointwise }}=0.0291\right)$ and DG-RZS ( $\left.p_{\text {pointwise }}=0.0271\right)$. Hence, the existence of a QTL for SCS near to the marker TGLA227 is confirmed. Within segregating families no consistent QTL-marker haplotype could be observed.

The genetic map estimated from the second data set covers $43 \mathrm{cM}$ (see Table 2 for further information). The marker order is in correspondence to previously published marker maps (HEYEN et al., 1999, VÅGE et al., 2000, THOMSEN et al., 2000, VIITALA et al., 2003).

Table 2

Genetic map and marker information (Genetische Karte und Markerinformationen)

\begin{tabular}{lccccc}
\hline Marker & BM7109 & ILSTS002 & BMS2639 & BM2078 & TGLA227 \\
\hline Relative position cM & 0.0 & 10.9 & 13.0 & 34.5 & 43.0 \\
Informative meioses & 991 & 966 & 1381 & 1397 & 1549 \\
Heterozygous grandsires* & 26 & 26 & 32 & 32 & 33 \\
Alleles & 10 & 8 & 9 & 10 & 11 \\
\hline *36 sires genotyped for BM7109, ILSTS002, BMS2639 and BM2078, 35 sires genotyped for TGLA227
\end{tabular}

For all four phenotypic classes a QTL was mapped at position $43 \mathrm{cM}$. The plot of the test statistic along the considered chromosomal region is shown in the Figure. The traits DYD $\mathrm{DSS}_{\mathrm{SC}-2 \mathrm{~L}}$ and DG-RZS reached the $10 \%$ chromosomewise significance level across all families. The results of the individual family analysis are shown in Table 3. For all other analysed traits only a highly significant QTL effect for udder depth was detected at position $30 \mathrm{cM}\left(\right.$ p $\left._{\text {chromosomewise }}=0.01\right)$ across all families.

The results of the two-QTL model of the second data set revealed a peak in the test statistic at positions 34 and 43 with an error probability of pointwise $=0.0215,0.0246$, 0.0571 and 0.1030 for DG-RZS, DYD $\mathrm{SCS}-2 \mathrm{~L}_{\mathrm{L}}, \mathrm{DYD}_{\mathrm{SCS}-1 \mathrm{~L}}$ and $\mathrm{DYD}_{\mathrm{SCS}-3 \mathrm{~L}}$, respectively (two QTL vs no QTL) and $\mathrm{p}_{\text {pointwise }}=0.1437,0.1782,0.2993$ and 0.2703 for DG-RZS,

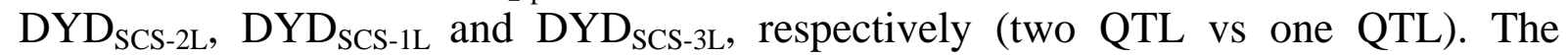
grandsires putatively heterozygous at the QTL are listed in Table 4. Here no correction for multiple testing was performed as these results should only be used as an indicator for a second putative QTL on BTA18 rather than a statistical proof for the existence of a second QTL. Therefore, no sophisticated model comparison was conducted, either. 


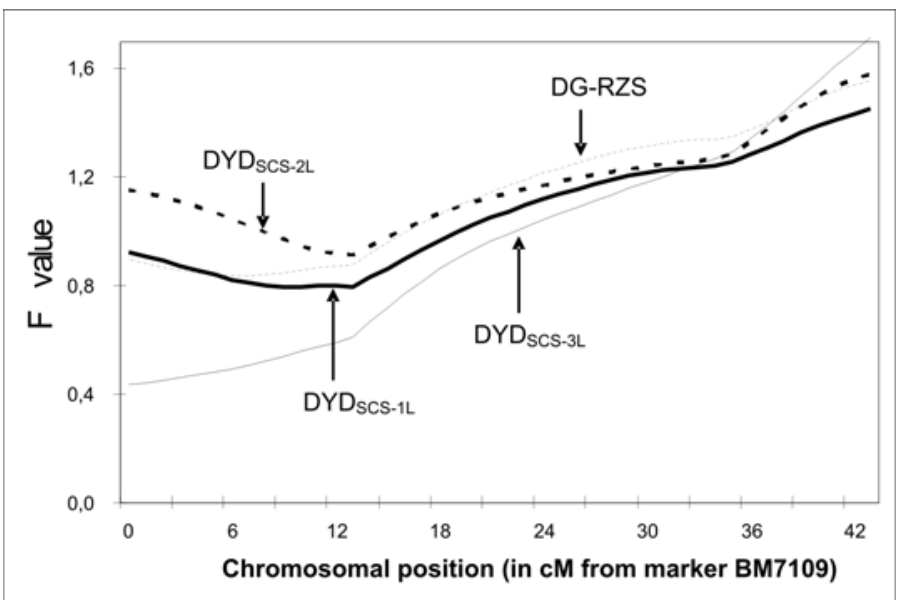

Figure: Plot of the test statistic along the considered chromosomal region of BTA18

DYD $_{\mathrm{SCS}-1 \mathrm{~L}}, \mathrm{DYD}_{\mathrm{SCS}-2 \mathrm{~L}}, \mathrm{DYD}_{\mathrm{SCS}-3 \mathrm{~L}}$ : daughter yield deviations for $1^{\text {st }}, 2^{\text {nd }}, 3^{\text {rd }}$ lactation; DG-RZS: de-regressed estimated breeding value of somatic cell score. For the marker positions see Table 2.

(Plot der Teststatistik im Bereich der untersuchten Region von BTA18)

Table 3

Pointwise and experimentwise error probabilities, FDR-q values for the most significant families for QTL position $43 \mathrm{cM}$, results from the one-QTL model and both data sets (Punktweit und experimentweit Irrtumswahrscheinlichkeiten, FDR-q Wert für die signifikantesten Familien QTL-Effekt, p- und q-Werte in signifikanten Familien für QTL-Position in der Nähe des Markers TGLA227, Ergebnisse des Ein-QTL-Modells und beiden Datensätzen)

\begin{tabular}{|c|c|c|c|c|}
\hline Trait class & Family & Ppointwise & Pexperimentwise & FDR-q value \\
\hline \multirow[t]{9}{*}{$\overline{D G-R Z S ~}(\mathrm{~m}=51)$} & 44 & 0.0017 & 0.0831 & 0.0867 \\
\hline & 4 & 0.0083 & 0.3469 & 0.2121 \\
\hline & 35 & 0.0202 & 0.6469 & 0.3435 \\
\hline & 8 & 0.0275 & 0.7590 & 0.3508 \\
\hline & 2 & 0.0402 & 0.8764 & 0.3663 \\
\hline & 48 & 0.0475 & 0.9164 & 0.3663 \\
\hline & 21 & 0.0503 & 0.9280 & 0.3663 \\
\hline & 28 & 0.0779 & 0.9840 & 0.4644 \\
\hline & 49 & 0.0937 & 0.9934 & 0.4644 \\
\hline \multirow[t]{6}{*}{$\mathrm{DYD}_{\mathrm{SCS}-1 \mathrm{~L}}(\mathrm{~m}=43)$} & 8 & 0.0018 & 0.0743 & 0.0495 \\
\hline & 44 & 0.0023 & 0.0943 & 0.0495 \\
\hline & 4 & 0.0058 & 0.2198 & 0.0825 \\
\hline & 21 & 0.0397 & 0.8252 & 0.4273 \\
\hline & 2 & 0.0728 & 0.9612 & 0.6259 \\
\hline & 28 & 0.0877 & 0.9807 & 0.6283 \\
\hline \multirow[t]{5}{*}{$\mathrm{DYD}_{\mathrm{SCS}-2 \mathrm{~L}}(\mathrm{~m}=35)$} & 44 & 0.0023 & 0.0774 & 0.0779 \\
\hline & 4 & 0.0054 & 0.1722 & 0.0779 \\
\hline & 8 & 0.0067 & 0.2090 & 0.0779 \\
\hline & 35 & 0.0237 & 0.5687 & 0.2078 \\
\hline & 12 & 0.0884 & 0.9609 & 0.5460 \\
\hline \multirow[t]{3}{*}{$\mathrm{DYD}_{\mathrm{SCS}-3 \mathrm{~L}}(\mathrm{~m}=14)$} & 44 & 0.0015 & 0.0208 & 0.0210 \\
\hline & 8 & 0.0288 & 0.3356 & 0.2015 \\
\hline & 4 & 0.0915 & 0.7390 & 0.3692 \\
\hline
\end{tabular}

DYD $_{\text {SCs-1L }}$, DYD $_{\text {SCS-2L, }}$ DYD $D_{\text {SCS-3L }}$ : daughter yield deviations for 1., 2., 3. lactation; DG-RZS: de-regressed estimated breeding value of somatic cell score; $\mathrm{m}$ : number of families

The QTL effects from family 1 to 37 were estimated by QTL Express, family 38 to 51 by SAS GLM analysis. p, q and $\mathrm{p}_{\mathrm{B}}$ are the p-value, false discovery rate and Bonferroni $p$-value, $m$ is the number of families 
Table 4

Pointwise error probabilities for the families with a significant QTL at position 34 cM (P1) and position 43 cM (P2), results from the two-QTL model and second data set (Punktweite Irrtumswahrscheinlichkeitseffekt an chromosomaler Position 34 cM (P1) und 43 cM (P2), Ergebnisse des Zwei-QTL-Modells und des zweiten Datensatzes)

\begin{tabular}{|c|c|c|c|c|c|c|c|c|}
\hline \multirow[b]{2}{*}{ Family } & \multicolumn{2}{|c|}{ DG-RZS } & \multicolumn{2}{|c|}{ DYD $_{\text {SCS-1L }}$} & \multicolumn{2}{|c|}{ DYD $_{\text {SCS-2L }}$} & \multicolumn{2}{|c|}{$\mathrm{DYD}_{\mathrm{SCS}-3 \mathrm{~L}}$} \\
\hline & $\mathrm{P} 1$ & $\mathrm{P} 2$ & $\mathrm{P} 1$ & $\mathrm{P} 2$ & $\mathrm{P} 1$ & $\mathrm{P} 2$ & $\mathrm{P} 1$ & $\mathrm{P} 2$ \\
\hline 2 & 0.4322 & 0.6146 & 0.0910 & 0.1334 & - & - & 0.0955 & 0.1106 \\
\hline 4 & 0.8949 & 0.1227 & 0.7234 & 0.2062 & 0.2846 & $\underline{0.0140}$ & 0.8779 & 0.6203 \\
\hline 6 & 0.8428 & 0.6216 & 0.6651 & 0.4269 & $\underline{0.0299}$ & $\underline{0.0159}$ & - & - \\
\hline 8 & 0.5345 & 0.9297 & 0.8037 & 0.4731 & 0.6387 & 0.0064 & 0.9489 & 0.5728 \\
\hline 16 & 0.0531 & 0.1163 & 0.1466 & 0.2159 & 0.8298 & 0.8645 & 0.3684 & 0.4832 \\
\hline 19 & 0.4864 & 0.3678 & 0.3894 & 0.3576 & 0.5402 & 0.7746 & 0.1368 & 0.0862 \\
\hline 21 & 0.6641 & 0.1113 & 0.5776 & 0.0773 & 0.9655 & 0.2477 & - & - \\
\hline 22 & 0.2823 & 0.2207 & $\underline{0.0338}$ & $\underline{0.0276}$ & 0.4793 & 0.2158 & - & - \\
\hline 24 & $\underline{0.0143}$ & 0.0523 & 0.0512 & 0.0629 & 0.4575 & 0.6289 & 一 & - \\
\hline 25 & $\underline{0.0166}$ & $\underline{0.0324}$ & $\underline{0.0362}$ & 0.1013 & $\underline{0.0216}$ & 0.2426 & - & - \\
\hline 27 & 0.1629 & 0.1626 & 0.0720 & 0.0700 & - & - & - & - \\
\hline 28 & 0.5264 & 0.2530 & 0.6092 & 0.3113 & 0.2561 & 0.0999 & - & - \\
\hline 34 & $\underline{0.0302}$ & 0.0672 & 0.0745 & 0.1058 & $\underline{0.0382}$ & 0.9591 & - & - \\
\hline 35 & 0.6859 & $\underline{0.0388}$ & 0.8037 & 0.2023 & 0.4002 & $\underline{0.0233}$ & - & - \\
\hline 37 & 0.0246 & 0.0343 & $\underline{0.0373}$ & 0.0231 & 0.0557 & $\mathbf{0 . 0 1 5 7}$ & 0.0580 & $\underline{0.0141}$ \\
\hline
\end{tabular}

$\mathrm{DYD}_{\mathrm{SCS}-1 \mathrm{~L}}, \mathrm{DYD}_{\mathrm{SCS}-2 \mathrm{~L}}, \mathrm{DYD}_{\mathrm{SCS}-3 \mathrm{~L}}$ : daughter yield deviations for 1., 2., 3. lactation; DG-RZS: de-regressed estimated breeding value of somatic cell score

Bold numbers reach a $10 \%$ pointwise significance; bold numbers with underline reach a $5 \%$ pointwise significance; and bold numbers in italics reach a $1 \%$ pointwise significance

\section{Discussion}

Several studies have reported QTL for SCS on chromosome 18: between BM7109 and ILSTS002 (SCHROOTEN et al., 2000), between BMS2639 and TGLA227 (SCHULMAN et al., 2004), between BMS1355 and TGLA227 (HOLMBERG and ANDERSSON-EKLUND, 2004), and at TGLA227 (KÜHN et al., 2003; SCHULMAN et al., 2004). ASHWELL et al. (1997) found a QTL for SCS near microsatellite marker BM2078 corresponding to the position of $34.5 \mathrm{cM}$ in our study, though the authors were unable to reproduce it in ASHWELL et al. (2004). In our study, the highest test statistic of the analysis of the second data set for all four SCS phenotypic classes was found at the chromosomal position of marker TGLA227 at $43 \mathrm{cM}$. The existence of the SCS QTL is therefore confirmed at this chromosomal position in the German Holstein dairy cattle population, especially since both data sets analysed are independent and showed significant SCS-QTL effects at marker TGLA227. The families putatively heterozygous at the QTL (Table 3) can be used for further investigations regarding SCS. Thereby the inferences should be made using either the DYD $\mathrm{DSS}_{\mathrm{SC}-1 \mathrm{~L}}$ or the DR-RZS phenotypic class due to a potential selection bias when using solely phenotypes from higher lactations.

The results of the two-QTL model applied to the second data set revealed a second putative SCS QTL next to marker BM2078, where ASHWELL et al. (1997) reported an SCS QTL. Interestingly, some families showing no significant marker effects, when the one-QTL model was used, do so with a two-QTL model. In these families the two QTL have effects of similar quantity but with an opposite sign. This suggests that the two QTL effects oppose each other, so that these families appeared to be QTL 
homozygous in the one-QTL model. The results indicate that there could be another QTL at $34 \mathrm{cM}$ in the same range of chromosome 18. SCHULMAN et al. (2004) did not fit a two-QTL model for SCS because they had no indication of two separate QTL positions on the same chromosome; ASHWELL et al. (2004) found no evidence favouring a two-QTL- over a one-QTL model in their whithin- and across-family analyses for SCS.

The QTL transition probabilities at position 34 might also be determined by the marker TGLA227 (multi-marker approach), hence the QTL at this position could be a shadow effect of the QTL at TGLA227 rather than a real second QTL. However, the impact of TGLA227 on the QTL transition probability at $34 \mathrm{cM}$ might be only small, because marker BM2078 is very informative itself. Additionally, different families segregated at both QTL using the 2-QTL model (Table 4), which can be interpreted against a shadow effect of the TGLA227 QTL. BRINK (2003) reported two peaks for the QTL of SCS at positions $88 \mathrm{cM}$ and $122 \mathrm{cM}$, corresponding to $16 \mathrm{cM}$ and $43 \mathrm{cM}$ in our study, respectively. In the study of BRINK (2003) a denser marker map was used and, therefore, the possibility of shadow effects was almost excluded.

The QTL effect for udder depth at position $30 \mathrm{cM}$ could be due to the correlation of this trait with SCS (LUND et al., 1994).

Several studies (e.g., GOLDAMMER et al., 2002; BRUNNER et al., 2003) have reported that the telomeric region of BTA18 exhibits high similarity to the HSA19q region in humans, that contains several gene families with effect on the immune system such as the SIGLEC- (sialic acid binding Ig-like lectin), the KIR- (killer cell immunoglobulin-like receptor) and the LILR (leukocyte immunoglobulin-like receptor) gene clusters. For the peak at $34 \mathrm{cM}$, there are a lot of these above mentioned genes possibly suitable as candidates for further studies.

From comparative genome analysis, we still do not know any candidate genes near the marker TGLA227 except of A1BG showing homology to the immunoglobulin-family (ISHIOKA et. al, 1986). This gene is a ligand of CRISP3 (UDBY et al., 2004), a gene involved in innate immunity (UDBY et al., 2002).

\section{Conclusion}

A one-QTL and two-QTL model were applied to the data provided for this study. The results strongly support the hypothesis that the marker TGLA227 is linked to a QTL for SCS segregating in German Holstein population in some half-sib families. The two-QTL analysis revealed the possibility of a second QTL for SCS in the same chromosomal region. Finemapping the QTL for SCS in the specific region of BTA18 might resolve the question if the two QTL hypothesis is correct.

\section{Acknowledgements}

The authors would like to thank the German Academic Exchange Service (DAAD) for its financial support for guest scientist NX, the German Cattle Breeders Federation (ADR) and Vereinigte Informationssysteme Tierhaltung w.V. (VIT) for their data supply and the National Major Basic Research Development Program of China (G2000016104) for the international travel expenses.

\section{References}

ASHWELL, M.S.; REXROAD JR., C.E.; MILLER, R.H.; VANRADEN, P.M.; DA, Y.:

Detection of loci affecting milk production and health traits in an elite US Holstein population using microsatellite markers. Anim. Genet. 28 (1997), 216-222 
ASHWELL, M.S.; HEYEN, D.W.; SONSTEGARD, T.S.; VAN TASSELL, C.P.; DA, Y.; VANRADEN, P.M.; RON, M.; WELLER, J.I.; LEWIN, H.A.:

Detection of quantitative trait loci affecting milk production, health, and reproductive traits in Holstein Cattle. J. Dairy Sci. 87 (2004), 468-475

BENJAMINI, I.; HOCHBERG, Y.:

Controlling the false discovery rate: a practical and powerful approach to multiple testing. J. Roy. BRINK, M.: Statist. Soc. Ser. B 57 (1995), 289-300

Ein Beitrag zur Feinkartierung von QTL-Regionen für Eutergesundheit beim Rind. Schriftenreihe des Instituts für Tierzucht und Tierhaltung der Christian-Albrechts-Universität zu Kiel 142 (2003)

BRUNNER, R.M.; SANFTLEBEN, H.; GOLDAMMER, T.; KÜHN, C.; WEIKARD, R.; KATA, S.R.; WOMACK, J.E.; SCHWERIN, M.:

The telomeric region of BTA18 containing a potential QTL region for health in cattle exhibits high similarity to the HSA19q region in humans. Genomics 81 (2003), 270-278

GOLDAMMER, T.; KATA, S.R.; BRUNNER, R.M.; DORROCH, U.; SANFTLEBEN, H.; SCHWERIN, M.; WOMACK, J.E.:

A comparative radiation hybrid map of bovine chromosome 18 and homologous chromosomes in human and mice. Proc. Natl. Acad. Sci. USA 99 (2002), 2106-2111

GREEN, P.; FALLS, K.; CROOKS, S.: Documentation of CRI-MAP, version 2.4, St. Louis: Washington University School of Medicine (1990)

HEYEN, D.W.; WELLER, J.I.; RON, M.; BAND, M.; BEEVER, J.E.; FELDMESSER, E.; DA, Y.; WIGGANS, G.R.; VANRADEN, P.M.; LEWIN, H.A.:

A genome scan for QTL influencing milk production and health traits in dairy cattle. Physiol. Genomics 11 (1999), 165-175

HOLMBERG, M.; ANDERSSON-EKLUND, L.:

Quantitative trait loci affecting health traits in Swedish dairy cattle. J. Dairy Sci. 87 (2004), 2653-2659

ISHIOKA, N.; TAKAHASHI, N., PUTNAM, F.W.:

Amino acid sequence of human plasma $\alpha_{1}$ B-glycoprotein: Homology to the immunoglobulin supergene family. Proc. Natl. Acad. Sci. USA 83 (1986), 2363-2367

KNOTT, S.A.; ELSEN, J.M.; HEALY, C.S.:

Methods for multiple marker mapping of quantitative trait loci in half-sib populations. Theoret. Appl. Genet. 93 (1996), 71-80

KÜHN, CH.; BENNEWITZ, J.; REINSCH, N.; XU, N.; THOMSEN, H.; LOOFT, C.; BROCKMANN, G.A.; SCHWERIN, M.; WEIMANN, C.; HIENDLEDER, S.; ERHARDT, G.; MEDJUGORAC, I.; FÖRSTER, M.;

BRENIG, B.; REINHARDT, F.; REENTS, R.; RUSS, I.; AVERDUNK, G.; BLÜMEL, J.; KALM, E.: Quantitative trait loci mapping of functional traits in the German Holstein cattle population. J. Dairy Sci. 86 (2003), 360-368

LUND, T.; MIGLIOR, F.; DEKKERS, J.C.M.; BURNSIDE, E.B.: Genetic relationships between clinical mastitis, somatic cell count, and udder conformation in Danish Holsteins. Livest. Prod. Sci. 39 (1994), 243-251

RODRIGUEZ-ZAS, S.L.; SOUTHEY, B.R.; HEYEN, D.W.; LEWIN, H.A.: Interval and composite interval mapping of somatic cell score, yield, and components of milk in dairy cattle. J. Dairy Sci. 85 (2002), 3081-3091

SCHROOTEN, C.; BOVENHUIS, H.; COPPIETERS, W.; VAN ARENDONK, J.A.M.: Whole genome scan to detect quantitative trait loci for conformation and functional traits in dairy cattle. J. Dairy Sci. 83 (2000), 795-806

SCHULMAN, N.F.; VIITALA, S.M.; DE KONING, D.J.; VIRTA, J.; MÄKI-TANILA, A.; VILKKI, J.H.: Quantitative trait loci for health traits in Finnish Ayrshire cattle. J. Dairy Sci. 87 (2004), 443-449

SEATON, G.; HALEY, C.S.; KNOTT, S.A.; KEARSEY, M.; VISSCHER, P.M.: QTL Express: mapping quantitative trait loci in simple and complex pedigrees. Bioinformatics 18 (2002), 339-340

SPELMAN, R.J.; BOVENHUIS, H.:

Moving from QTL experimental results to the utilization of QTL in breeding programmes. Anim. Genet. 29 (1998), 77-84

SPELMAN, R.J.; COPPIETERS, W.; KARIM, L.; VAN ARENDONK, J.A.M.; BOVENHUIS, H.: Quantitative trait loci analysis for five milk production traits on chromosome six in the Dutch HolsteinFriesian population. Genetics 144 (1996), 1799-1808

THOMSEN, H.; REINSCH, N.; XU, N.; LOOFT, C.; GRUPE, S; KÜHN, C.; BROCKMANN, G.A.; SCHWERIN, M.; LEYHE-HORN, B.; HIENDLEDER, S.; ERHARDT, G.; MEDJUGORAC, I.; RUSS, I; FÖRSTER, M.; BRENIG, B.; REINHARDT, F.; REENTS, R.; BLÜMEL, J.; AVERDUNK, G.; KALM, E.: A male bovine linkage map for the ADR granddaughter design. J. Anim. Breed. Genet. 117 (2000), 289-306 
THOMSEN, H.; REINSCH, N.; XU, N.; LOOFT, C.; GRUPE, S.; KÜHN, C.; BROCKMANN, G.A.; SCHWERIN, M.; LEYHE-HORN, B.; HIENDLEDER, S.; ERHARDT, G.; MEDJUGORAC, I.; RUSS, I.; FÖRSTER, M.; BRENIG, B.; REINHARDT, F.; REENTS, R.; BLÜMEL, J.; AVERDUNK, G.; KALM, E.: Comparison of estimated breeding values, daughter yield deviations and de-regressed proofs within a whole genome scan for QTL. J. Anim. Breed. Genet. 118 (2001), 357-370

UDBY, L; CALAFAT, J., SØRENSEN, O.E.; BORREGAARD, N.; KJELDSEN, L.: Identification of human cysteine-rich secretory protein 3 (CRISP-3) as a matrix protein in a subset of peroxidase-negative granules of neutrophils and in the granules of eosinophils. J. Leuk. Biol. 72 (2002), 462-469

UDBY,L.; SØRENSEN, O.E.; PASS, J.; JOHNSEN, A.H.; BEHRENDT, N.; BORREGAARD, N.; KJELDSEN, L.:

Cysteine-rich secretory protein 3 is a ligand of $\alpha_{1} B$-glycoprotein in human plasma. Biochem. 43 (2004), $12877-12886$

VÅGE, D.I.; OLSAKER, I.; KLUNGLAND, H.; GOMEZ-RAYA, L.; LIEN, S.:

A male genetic map designed for quantitative trait loci mapping in Norwegian cattle. Acta Agric. Scand., Sect. Anim. Sci. 50 (2000), 56-63

VIITALA, S.M.; SCHULMAN, N.F.; DE KONING, D.J.; ELO, K.; KINOS, R.; VIRTA, A.; VIRTA, J.; MÄKITANILA, A.; VILKKI, J.H:

Quantitative trait loci affecting milk production traits in Finnish Ayrshire dairy cattle. J. Dairy Sci. 86 (2003), 1828-1836

Received: 2005-09-30

Accepted: 2006-03-09

Author's addresses

Prof. Dr. NINGYING XU

College of Animal Science, Zhejiang University, CN-310029 Hangzhou, P. R. China

Dipl.-Biol. SVEN PAUL, PD Dr. habil. JÖRN BENNEWITZ*, Prof. Dr. GEORG THALLER, Prof. Dr. Dr. hc. mult. ERNST KALM

Institute of Animal Breeding and Husbandry, University of Kiel, Olshausenstraße 40, D-24098 Kiel, Germany

${ }^{*}$ Corresponding author

E-Mail: jbennewitz@tierzucht.uni-kiel.de

PD Dr. habil. CHRISTA KÜHN, Prof. Dr. NORBERT REINSCH, Prof. Dr. MANFRED SCHWERIN

Research Institute for Biology of Farm Animals, D-18196 Dummerstorf, Germany

FRITZ REINHARDT

United Datasystem Animal w.V., Heideweg 1, D-27283 Verden / Aller, Germany

Dr. HAUKE THOMSEN

Department of Genetics and Biotechnology, Research Center Foulum, DK-8830 Tjele, Denmark

Prof. Dr. GEORG ERHARDT, Dr. CHRISTINA WEIMANN

Institut of Animal Breeding and Genetics, Justus-Liebig-University Gießen, Ludwigstraße 21B D-35390 Gießen, Germany

Prof. Dr. SHARAD MISHRA

Department of Livestock Production and Management, College of Veterinary Science and Animal Husbandry, Indira Gandhi Agriculture University, Post Box no.-6,

Anjora, Durg, Chhattisgarh, India 